\title{
EL BARRIO DE LA EMBAJADA DE ESPAÑA EN ROMA EN LA SEGUNDA MITAD DEL SIGLO XVII*
}

\author{
MAXIMILIANO BARRIO GOZALO \\ Universidad de Valladolid
}

RESUMEN: A mediados del siglo XVII los embajadores extranjeros en Roma extienden la inmunidad de su palacio a un sector de la ciudad, el barrio de la embajada. Pero en el último tercio del siglo los papas luchan por suprimir estas jurisdicciones exentas. En este artículo, a través de la documentación vaticana y española, se estudia la evolución del barrio español y sus avatares hasta que el marqués de Cogolludo renuncia a su inmunidad y se abre un nuevo periodo de jurisdicción limitada.

Palabras Clave: España siglo XVII. Roma siglo XVII. Embajada de España en Roma. Historia de las relaciones internacionales.

ABSTRACT: In the middle of the XVIIth century the foreign ambassadors in Rome extend the immunity of his palace a sector of the city, the district of the embassy. But in the last third of the century the Popes try to suppress these exempt jurisdictions. In this article across the documentation Vaticana and Spanish, studies the evolution of the Spanish district and his vicissitudes until the Marquess of Cogolludo resigns his immunity, and there begins a new period of limited jurisdiction.

KEY WORDS: Spain XVIIth century, Rome XVIIth century. Embassy of Spain in Rome. History of the international relations.

El derecho internacional reconoce la inmunidad a los que desempeñan la representación diplomática y, por tanto, sus miembros no pueden ser juzgados

* Las abreviaturas utilizadas son las siguientes: AGS = Archivo General de Simancas; AMAE $=$ Archivo del Ministerio de Asuntos Exteriores, Madrid; ASV = Archivio Segreto Vaticano; BAV = Biblioteca Apostólica Vaticana, y BEESS = Biblioteca de la Embajada de España ante la Santa Sede, fondo de códices depositado en la Biblioteca de la Iglesia Nacional Española de Roma. 
ni castigados por las leyes del país ante el que están acreditados. Esta prerrogativa adquiere, sin embargo, un desarrollo especial en la corte romana, donde la autoridad papal no había conseguido frenar las reivindicaciones jurisdiccionales de algunas familias nobles, que reclamaban inmunidad para sus casas, y los embajadores extienden el privilegio concedido a su persona, familia y palacio también a un sector de la ciudad en torno a su residencia. Los diplomáticos, en consecuencia, pretenden y consiguen que la justicia de los soberanos ante los que están acreditados no actúe en su circunscripción ${ }^{1}$. Y esta zona, de confines variables, se conoce con el nombre de quartiere, que los diplomáticos españoles traducen por barrio o cuartel de la embajada, que son los términos que utilizaré2.

Por lo que respecta al barrio español, el hecho de que la embajada cuente con un palacio propiedad de la corona desde $1647^{3}$, así como la importancia política de la monarquía hispana, permite a los representantes del rey católico extender y controlar el barrio en mayor medida que a otros diplomáticos, a pesar de la oposición de los papas y, en ocasiones, también de los representantes franceses, que reivindican el control de la pendiente de la Trinidad del Monte, en cuya cima se levantaba la iglesia de San Francisco de Paula, de los frailes mínimos, que estaba bajo la protección del rey de Francia.

Aunque la documentación es abundante, el tema de los barrios de los embajadores no ha suscitado demasiado interés entre los estudiosos, si se exceptúan algunos trabajos referentes al pontificado de Inocencio XI (1676-1689) y al barrio francés, protagonista de los incidentes más conocidos ${ }^{4}$. En cambio, el barrio español sólo ha suscitado unas breves pinceladas por parte de José María Marqués, al estudiar la nunciatura de Savo Millini (1675-1685)5 y de Alessandra Anselmi al estudiar el palacio de la embajada 6 . Por esta razón, en las pági-

1 Hugon, A.: Au service du Roi Catbolique. Honorables Ambassadeurs et divins espions, Madrid, 2004, pp. 211-231, ofrece unas ideas precisas sobre las inmunidades diplomáticas; y TocCI, M.: «Immunità internazionali e ordinamento interno a Roma sotto Innocenzo XI», Revista del diritto italiano (Roma), 59 (1986), pp. 203-226, se centra en el caso romano.

2 BEESs, ms. 405, ff. 41-51. ¿Qué cosa son los quarteles, su origen y lo que se ha becho hasta abora por abolirlos?, s/f., donde también se hace referencia a distintas bulas pontificias contra los barones, cardenales y embajadores de los príncipes extranjeros que pretenden la inmunidad en las zonas contiguas a sus palacios.

3 Anselmi, A.: Il palazzo dell'Ambasciata di Spagna presso la Santa Sede, Roma, 2001, pp. 53103; y CONDe De Altea: Historia del Palacio de España en Roma, Madrid, 1972.

${ }_{4}^{4}$ De BojAnI, F.: La question du quartier a Rome a la fin du XVII siècle. Louis XIV et le S. Siège, Roma, 1908. Este autor no hace ninguna referencia al barrio español, y la obra de PASTOR, L.: Historia de los Papas, XXXII, Barcelona, 1952, pp. 283-328, sólo contiene breves alusiones.

5 MARQUeS, J. M.:»La Santa Sede y la España de Carlos II. La negociación del nuncio Millini (1675-1685)», Antológica Annua (Roma), 28-29 (1981-82), pp. 30-37.

${ }^{6}$ ANSELMI, A.: Il palazzo..., pp. 171-179. La autora reasume y completa en este capítulo lo que dice en «Il quartiere dell'Ambasciata di Spagna a Roma», in CALABI, D. e LANARO, P. (a cura di): La città italiana e $i$ luoghi degli stranieri XIV-XVIII secolo, Bari, 1998, pp. 206-221.La misma autora ha publicado «El marqués del Carpio y el barrio de la Embajada de España en Roma (1677- 
nas siguientes ofrezco unas ideas sobre el barrio español, centrándome en el esfuerzo pontificio por suprimir la inmunidad de los barrios de los embajadores. Objetivo que en buena medida consigue Inocencio XI después de fuertes presiones, amenazas y algunos conflictos. Hay que recordar, no obstante, que la limitación de la jurisdicción no es consecuencia de la crisis de la monarquía española, sino de la política emprendida por Inocencio XI para abolir la pretendida inmunidad de los cuarteles de los embajadores. Por ello afecta lo mismo al español que al francés, al veneciano que al polaco, al portugués que al del Imperio. Otra cosa es que la corte romana presione a la debilitada España para que sea la primera en renunciar al barrio y sirva de ejemplo a los demás soberanos ${ }^{7}$.

\section{EL QUARTIERE ESPAÑOL}

El barrio de la embajada española parece que es el que se consolida primero $\mathrm{y}$, sin duda, el que adquiere mayor extensión. En un principio, según indica don Pedro de Aragón, sólo abarca la plaza de España hasta el palacio de Propaganda Fide, dos pequeñas calles a ambos lados del palacio y la que está a su espalda ${ }^{8}$. Un plano de 1660 incluye varias calles más, y en 1670 ya ocupa una extensión de 712 casas, situadas en una zona de gran vitalidad ciudadana, siete fondas y 157 tiendas y talleres artesanales, y su límite exterior lo marcan las calles Babuino, hasta la esquina de la Croce, Bocca di Leone, de la Vite, Santa Maria dei Fiori, Mercede, Due Macelli, subida a Trinitá dei Monti y San Sebastianello.

«Además del Palacio - dice la relación-, abarca toda la plaza desde el palacio de Propaganda Fide hasta el otro cantón de la hostería del Cavalletto y el circuito del Monte de la Trinidad, juntamente con las dos calles a uno y otro lado del dicho palacio de Propagada, hasta San Andrea delle Frate, exclusive, con la subida de San Giuseppe, y la calle de la Vite, desde el cantón de la iglesia de San Giovannino, frente al cantón del monasterio de San Silvestro hasta Propaganda. La calle Ferratina, desde la hostería del Gambaro hasta Propaganda. La calle Borgoñona, desde el cantón de la hostería del Gambaro de la parte de atrás hasta el pa-

1683)», en Alvarez-Osorio, A., y Garcia Garcia, B. J. (eds.): La Monarquía de las naciones. Patria y naturaleza en la monarquía española, Madrid, 2004, pp. 563-596. En cambio, OCHOA BRUN, M. A.: Historia de la diplomacia española. La Edad Barroca, II, Madrid, 2006, pp. 255-262, se limita a hacer mención a las inmunidades de los embajadores, pero no dice nada del cuartel en las pp. 156161, que dedica a la embajada romana en el reinado de Carlos II.

7 No existe un estudio completo y actual sobre las relaciones entre Roma y Madrid en la segunda mitad del siglo XVII, sólo aportaciones sobre algunos aspectos concretos, como la de Signorotto, G.: «Lo squadrone volante. Cardinali 'liberi' e la política europea nella seconda metà del XVII secolo», en Signorotto G., y VisCeglia, M. A. (a cura di): La Corte di Roma tra Cinque e Seicento. «Teatro» della politica europea, Roma, 1998, pp. 93-137.

8 AGS, Estado, leg. 3119. Consulta del Consejo de Estado, 11 agosto 1682. 
lacio del Señor Embajador. La calle de Condotti, desde el palacio del marqués Núñez, inclusive, hasta dicha plaza. Todas las demás callejuelas que van de una parte a otra de las dichas calles de Condotti, Borgoñona, Ferratina y de la Vite, hasta el cantón del palacio del caballero Bernini, con exclusión de la calle que va desde San Andrea delle Fratte a la plaza de las monjas de San Silvestre»?.

El marqués de Carpio, al poco de hacerse cargo de la embajada (16771682) amplia el barrio a las calles de la Croce, Belsiana, Gambero, Plaza San Silvestro, Pozzeto. Bufalo, San Andrea delle Fratte, Capo de Case, Gregoriana, Trinità dei Monti y rampa de San Sebastianello, lo que supone cuatrocientas casas más ${ }^{10}$. En 1682 el marqués renuncia a esta ampliación por orden del gobierno español, pero el papa no lo acepta, porque quiere la cesión de su totalidad. El embajador continúa en su posesión hasta que marcha a Nápoles para ocupar el cargo de virrey, quedando como encargado de negocios el agente Francisco Bernardo de Quirós, que se compromete a defender su inmunidad. Pero, a los pocos días de salir el marqués del Carpio para su nuevo destino, el 14 y 15 de enero de 1683, los esbirros pontificios entran en el cuartel y pasan por sus calles y por la plaza de España, mostrando públicamente la voluntad pontificia de acabar con los barrios y jurisdicciones exentas ${ }^{11}$.

Los límites del barrio estaban señalados por piedras blancas o cantones con las siglas A.D.S, que significan Ambasciata di Spagna, y los derechos que el embajador ejercía se llamaban «el franco» o la «jurisdicción del cuartel de la plaza de España», como se lee en los documentos del Archivo de la Embajada, donde se afirma que la embajada ejercía la jurisdicción en la plaza «per immemoriale, amplissima concessione di cui godevano i reppresentanti del re nel quartiere», y consistía en la prohibición de ejercer actos de justicia sin la autorización del embajador y en el derecho de tener una guardia o policía propia ${ }^{12}$.

Dos causas explican la expansión de los barrios. En primer lugar, la alianza de los embajadores, sobre todo del francés y el español, para defender las franquicias y la inmunidad de sus cuarteles ante la ofensiva pontificia contra la inmunidad de estas zonas. Y en segundo lugar, el consentimiento de la mayor parte de la población, que acepta de buen grado el control del ministro extranjero, en cuanto que aporta beneficios de carácter económico. Pues los comerciantes, taberneros y hosteleros colocan las armas de la corona que representa el embajador en sus establecimientos y los diplomáticos les entregan cartas de familiaridad para que gocen de la inmunidad diplomática y se libren del pago de los impuestos que gravan las mercancías, sobre todo de los que soportan

9 ASV, Segr. Stato, Nunz. Diverse, vol. 295, ff. 81-85. Extensión del quartiere español en Roma. Año 1670. Otras copias en AGS, Estado, leg. 3119 y BEESS, ms. 448, ff. 272-275.

10 AGS, Estado, leg. 3120. Nota de quartieri che hoggi pretendono li spagnoli che non possono andarvi li sbirri.

${ }^{11}$ Ibíd., leg. 3119. Bernardo de Quirós a Carlos II. Roma 17 enero 1683.

12 AMAE, Santa Sede, leg. 92. 
mayor presión fiscal, como la cera, el papel y el vino. De esta forma, además de beneficiarse de las franquicias sobre los géneros extranjeros, la justicia pontifica no puede perseguirlos por los fraudes que cometen en la alteración de los géneros alimenticios. Por su parte, los embajadores obtienen por este medio mayor número de mercancías exentas de tasas y aumentan su prestigio personal. Es decir, las razones económicas y de prestigio explican la extensión de los barrios y su obstinada defensa ${ }^{13}$.

Los embajadores encargan al mayordomo la conservación y el gobierno del barrio, tanto de las calles, casas, tiendas y talleres como de los residentes, y es él quien concede licencia a los vendedores ambulantes, autoriza las salas de juego, vigila el alquiler de las habitaciones y sobre todo las hosterías, tiendas y talleres artesanos, cobrando impuestos con el pretexto de asegurarles la tranquilidad. La inmunidad territorial permite que se pueda jugar impunemente y son frecuentes las casas públicas de juego regentadas por algún familiar del embajador, sin que la autoridad papal pueda impedirlo. Lo único que puede hacer el gobernador de Roma es protestar y pedir a los embajadores que lo supriman o, al menos, que se practique con más discreción, como hace en 1645 con el conde de Oñate, invitándole a cerrar un casa de juego contigua a su palacio; pero el embajador se limita a responder que está dispuesto a hacerlo si lo hacen los demás embajadores, pues en sus barrios también hay casas públicas de juego ${ }^{14}$.

La inmunidad del cuartel también favorece la emigración de numerosas cortesanas o prostitutas. Es verdad que en esta zona su número ya era importante antes de que se instalase la embajada de España, pero luego se incrementa porque en el siglo XVII el entorno de la plaza de España se convierte en el centro hotelero más importante de la ciudad y en la zona residencial preferida por los forasteros que llegan a Roma a lo largo del año, pero sobre todo a pasar la estación invernal. Dos hechos favorecen su desarrollo: su cercanía a la Porta del Popolo, puerta de entrada para los viajeros que llegaban del Norte y, desde mediados del siglo, la inmunidad del barrio de la embajada española, pues los forasteros prefieren el régimen menos austero de cuartel español y las buenas habitaciones de los nuevos albergues, «che per essere di prim'ordine e percio più confortavili, venivano chiamati locande, per distinguerli dagli altri di minore propietà» ${ }^{15}$.

Los embajadores acreditados ante la corte romana se benefician de los derechos de franquicia aduanera, no solo de las mercancías que llevan al inicio de su embajada y los comestibles, sino también de los géneros y mercancías que reciben después, sin que la aduna pueda revisarlos, aunque sospeche que pueden ser géneros de contrabando. También tienen derecho al reembolso de los im-

13 ANSELMI, A.: Il palazzo..., p. 177.

${ }_{14}$ BAV, Ottoboni, ms. 3338. Aviso del 5 agosto 1645.

15 Romano, P. e Parini, P.: Piazza di Spagna. Nella Historia e nell'Arte, Roma, Palombi Editori, s. f., p. 76. 
puestos que pagan por los artículos comprados en Roma, especialmente los más gravados, como el papel, la cera y el vino, sin tener que presentar facturas para justificarlo, siendo suficiente la palabra del embajador ${ }^{16}$. La Cámara Apostólica reembolsa al nuevo embajador por los gastos que hace en su instalación una media de mil a dos mil escudos romanos, aunque algunos exigen una cantidad mayor y surgen disputas. El papa Clemente X (1670-1676) decide poner fin al abuso de la franquicia aduanera, que el embajador francés, duque d'Estrées, utilizaba de forma abusiva por su precaria situación económica, y con el decreto de 11 de septiembre de 1671 impone un arancel del 3 por 100 a todos los géneros y mercancías que entraban por la aduana con destino a los embajadores. El embajador francés siente vulnerados sus derechos y, en unión con los representantes del Imperio, España y Venecia, formulan una protesta contra el decreto, que el papa termina por derogar parcialmente, diciendo que la medida no afectaba a los embajadores ${ }^{17}$.

El papa Inocencio XI (1676-1689), para evitar estos problemas y frenar el aumento progresivo de la franquicia de las aduanas, que en el caso de los embajadores españoles se había multiplicado por cinco en los últimos años, pasando de una media anual de cinco mil escudos romanos en el sexenio 1658-1663, a veinte mil en el siguiente y a veintiocho en el periodo $1670-1676^{18}$, publica un decreto, disponiendo que en adelante no se abonarán más de dos mil escudos en concepto de franquicias, y sólo por las mercancías que entrasen en la ciudad. Quedaba por solucionar el problema de las mercancías introducidas por la aduana, cuyo pase firmaba el mayordomo del embajador, pues aunque las autoridades sospechasen que la cajas o fardos podían contener géneros de contrabando, el intento de revisarlo podía ocasionar un incidente diplomático, como sucede en agosto de 1678 con el mayordomo del marqués del Carpio, cuando va a retirar unos fardos y los aduaneros los abren para comprobar su contenido. El embajador lo considera una afrenta y propone pedir una satisfacción al gobierno pontificio $^{19}$. Para suprimir este abuso y evitar problemas, el papa dispone que las mercancías que los embajadores reciben del exterior, aunque estén libres de impuestos, pueden revisarse en la aduana.

Los embajadores de España y Francia también acostumbran a reclutar soldados en el Estado de la Iglesia, a pesar de la prohibición pontificia de hacer levas sin su licencia. Durante la primera mitad del siglo XVII las levas son frecuentes y así continúan en los años siguientes, dando ocasión a algunos motines populares contra los españoles, como sucede en 1650, 1677 o $1736^{20}$. Poco antes de la lle-

16 BEEss, ms. 448, ff. 276-278. Instrucción de Mons. Fantuzzi al nuncio Marescotti. Año 1670.

17 PASTOR, L.: Historia de los papas, XXXI, Barcelona, 1950, pp. 417-419. Más información en Lo SARDO, E.: Le gabelle e le dogane dei Papi in età moderna, Roma, 1994.

18 AGS, Estado, 3120. Importe de las franquicias de los embajadores españoles en Roma. Años 1644-1676.

19 Ibíd., leg. 3059. Consultas del Consejo de Estado, 4 septiembre y 8 y 29 octubre 1678.

${ }^{20}$ Romano, P. e Parini, P.: Piazza di Spagna...., pp. 51-56. 
gada del marqués del Carpio, el representante francés recluta alguna gente y el español, cardenal Nithard ${ }^{21}$, le imita, aprovechando que Inocencio XI había licenciado a parte de su guardia. El marqués del Carpio continúa la costumbre, pero a primeros de septiembre de 1677 el papa le pide que suspenda las levas para evitar represalias francesas y prohíbe hacerlas en todo el Estado Eclesiástico ${ }^{22}$.

La autoridad pontificia no acepta verse privada de la jurisdicción en una zona de la ciudad y publica edictos contra estos espacios de inmunidad para que ninguna persona, después de cometer un delito, pueda refugiarse en casa de cualquier señor, barón, cardenal o embajador, para impedir la acción de la justicia. Pero los embajadores afianzan cada vez más la inmunidad territorial en su barrio y su defensa provoca disputas y conflictos con el gobierno romano a lo largo del siglo. El primer incidente registrado tiene lugar en 1635, cuando la policía romana detiene a una mujer que vivía detrás del palacio de la embajada. Cuando la llevan detenida, se encuentran con el caballerizo del embajador y, pensando que el arresto era una ofensa a los privilegios de la embajada, echa mano de la espada y libera a la mujer. El marqués de Castel Rodrigo se queja al gobernador de Roma de poca cortesía por detener a una persona cerca de su casa, pero le responde que el respeto que se tenía a su casa y familia no podía extenderse a las casas vecinas ${ }^{23}$. Dos años después los esbirros intentan detener a un músico cerca del palacio y los soldados lo impiden. Don Juan de Chumacero, que entonces era embajador extraordinario, protesta ante el gobernador por la violación de la jurisdicción, pero le contesta que no se admite ninguna inmunidad territorial en la ciudad de Roma y, por tanto, los oficiales de justicia pueden ejercer su oficio en cualquier lugar de la ciudad, y acto seguido envía un número mayor de esbirros para que hagan la detención. El embajador vuelve a protestar ante el cardenal nepote y se queja de «que todo esto se hacia en venganza del suceso ocurrido en España, donde por una causa semejante se había azotado a un criado del nuncio», pero el cardenal se limita a responder que por encima de todo debía hacerse justicia y que si no procedía contra sus familiares era porque no creyeran que se hacía en venganza por lo sucedido en Madrid ${ }^{24}$.

En los años siguientes las detenciones se hacen con toda normalidad en la zona cercana al palacio, pero durante la embajada del conde de Siruela surgen de nuevo los enfrentamientos. En 1645 se acusa al conde de alojar una guarnición de soldados en el palacio de la embajada, de proteger a un armero borgoñón, que tenía tienda abierta en la plaza de España (entonces se llamaba todavía de la Trinidad), en la que vendía arcabuces y pistolas cortas a pesar de estar prohibido, e impedir la detención de los delincuentes, como hace con un espa-

${ }^{21}$ Se encarga interinamente de la embajada española en Roma desde 1671 hasta que llega el marqués del Carpio en mayo de 1677.

${ }_{22}$ AGS, Estado, leg. 3055. Bando che non si possa far soldati nello Stato Eclesiástico per servizio d'alcun principe. Roma 11 settembre 1677.

23 ASV, Segr. Stato, Nunz. Diverse, vol. 295, ff. , 2-3 y 39

${ }^{24}$ Ibid., ff. 3 y $41-42$. 
ñol que participa en la pelea ocurrida entre el cochero del agente de las iglesias de Portugal y unos españoles, que se hallaban en la plaza del Pueblo el día que hizo su entrada, de cuyas resultas el cochero quedó mal herido y otro miembro de la comitiva resultó muerto ${ }^{25}$. El gobierno pontificio protesta por el hecho y sobre todo para evitar que los demás representes extranjeros hagan lo mismo, pues por el principio de solidaridad y emulación que existía entre ellos lo que se permitía a uno lo hacían también los otros ${ }^{26}$.

Cuando el conde de Siruela termina su embajada, la corte romana pide a Felipe IV que de instrucciones precisas a su sucesor para evitar problemas de jurisdicción, pues desde hacía algún tiempo los embajadores españoles impedían el libre ejercicio de la justicia en la plaza que estaba delante de su palacio y en las calles y casas de su entorno, con lo cual no podían castigar los delitos que se cometían y perseguir a los delincuentes que allí se refugiaban. El Consejo de Estado examina la petición y se conforma con el parecer del conde de Monterrey, que defiende la inmunidad del palacio pero se opone a que se extienda a la plaza y a las calles adyacentes por los inconvenientes que podría acarrear,

«pues la inmunidad de la casa del embajador se extiende a pocos pasos delante de su puerta hacia dentro de la casa, sin que lo demás se pueda haber practicado sin detrimento grande de la justicia y gobierno, porque el quererlo extender a la plaza de la Trinidad (que es la que está delante de la casa del embajador) y demás calles y casas que se dice en el memorial sería hacer una separación de cuartel en Roma, de que resultarían grandísimos inconvenientes y muchos pecados y abominaciones, a que no debe dar lugar el justo ánimo de V. M., que puede servirse de mandar considerar que turbación fuera si en la corte de España intentarán tal los embajadores de las coronas, y lo que V. M. no puede permitir en su corte no es razón que se permita a los ministros de V. M. en la corte de otros príncipes» ${ }^{27}$.

El nuevo embajador, conde de Oñate, desde el principio de su embajada permite a los esbirros pontificios entrar en la plaza y en las calles vecinas para detener a los delincuentes e incluso, si alguno comete un delito grave y se refugia en su palacio, autoriza su entrada para detenerle. El conde no quiere turbar la buena armonía con el romano pontífice por disputas jurisdiccionales y lo mismo hace el duque del Infantado, aunque hacen lo posible por que no se hagan detenciones en el entorno del palacio de la embajada ${ }^{28}$.

A partir de la embajada del duque de Terranova (1653), cuando se restaura el palacio y se oficializa su posesión por parte de la corona española, las reivin-

${ }^{25}$ AGS, Estado, leg. 3116. Consultas del Consejo de Estado referentes a la salida de Roma del Conde de Siruela.

26 ASV, Segr. Stato, Spagna, vol. 88, ff. 24-25. Secretario de Estado a Nuncio. Roma 8 mayo 1645.

27 AGS, Estado, leg. 3013. Consulta del Consejo de Estado, 13 de julio 1646.

28 Ibíd., legs. 3015. Conde de Oñate a Felipe IV. Roma 16 agosto 1646; y 8680. Duque del Infantado a Felipe IV. Roma 27 junio 1650. 
dicaciones jurisdiccionales y la extensión de la zona en la que los embajadores pretenden que la policía pontificia no haga detenciones ni controles es cada vez mayor. En 1660 el embajador don Luis de Guzmán Ponce de León tiene problemas con el gobernador de Roma por la detención de una prostituta y de un joven aragonés en las cercanías del palacio ${ }^{29}$, y es ahora cuando se hacen los primeros planos para determinar los límites de la jurisdicción española en torno al palacio de la embajada, como el que presentan las autoridades romanas para demostrar que el arresto se había realizado fuera de la vista del palacio. La actitud conciliadora del embajador pone fin, al menos de momento, a la disputa por la inmunidad de la zona. Además, el Consejo de Estado le advierte que se olvide de las «cosas menudas y se reserve para las más importantes», entre las que no debe incluir la defensa de la jurisdicción en las calles cercanas al palacio, y el conde de Castrillo dice en el Consejo que «la inmunidad rigurosa no se extiende a otra casa que a la del embajador» ${ }^{30}$.

Si hasta 1662 la policía pontifica patrulla y hace detenciones en las calles cercanas al palacio de la embajada, después, como consecuencia del incidente de la guardia corsa con la familia del embajador de Francia, se produce un debilitamiento de la autoridad pontificia frente a las pretensiones jurisdiccionales de los embajadores, que forman una especie de frente común contra el gobernador de Roma durante dos décadas e incrementan la extensión y la inmunidad de los cuarteles. Los embajadores españoles aprovechan la coyuntura y amplían notablemente su jurisdicción. En 1670 el barrio ya alcanza una extensión importante y en 1678 el embajador marqués del Carpio puede vanagloriarse de controlar una zona que, además del palacio, incluye 850 casas y 206 tiendas, como se describe en la Memoria de la largueza y anchura que el quartel de España tiene, en el que se especifican las calles, plazas, iglesias, conventos, colegios, casas y tiendas, comprendiendo en su demarcación también el convento de la Trinidad del Monte de la orden de san Francisco de Paula de la nación francesa ${ }^{31}$.

La expansión del barrio español no solo preocupa a la autoridad pontificia sino también a los representantes franceses, que tratan de impedirlo con la construcción de una escalinata en la pendiente de la Trinidad del Monte, en cuya parte superior estaba la iglesia de los padres mínimos franceses. En 1655 el residente francés, que vivía al otro lado de la plaza de la Trinidad, en la subida de San Sebastianello, deja veinte mil escudos para la construcción de la escalinata, pero la iniciativa choca con la oposición española, que pretende incluir la pendiente en su jurisdicción, y con la pontificia, que desde hace años disputa a los padres mínimos la posesión de la pendiente, aunque los religiosos afirman que había sido adquirida por el rey de Francia junto con el terreno

${ }^{29}$ Ibíd., leg. 3033. Luis de Guzmán Ponce de León a Felipe IV. Roma 27 agosto 1660.

30 Ibíd., leg. 3033. Consulta del Consejo de Estado, 10 octubre 1660.

${ }^{31}$ Ibíd., leg. 3059. Breve memoria de la largura y anchura que el cuartel de España tiene, con sus calles y habitaciones. Año 1678. 
donde se había levantado la iglesia. Estos problemas y, sobre todo, la propuesta de colocar la estatua de Luis XIV en medio de la escalinata provocan la oposición de Alejandro VII y la paralización del proyecto ${ }^{32}$. Los franceses, sin embargo, no renuncian a imponer su presencia en la zona disputada y a finales de 1661 realizan un gran aparato efímero, patrocinado por el cardenal Barberini, para celebrar el nacimiento del delfín ${ }^{33}$. El papa, que no había permitido la construcción de la escalinata para que no se apoderasen de la zona, acepta su ocupación ocasional para calmar a Luis XIV y controlar las tentativas expansionistas del embajador español. La respuesta española no se hace esperar, dos semanas después el embajador don Luis de Guzmán Ponce de León, para no ser menos, organiza grandes festejos en la plaza para celebrar el nacimiento del infante don Carlos $^{34}$.

Las disputas jurisdiccionales de la década se cierran a favor de los españoles con la complicidad de Alejandro VII, como resulta del plano de Roma editado por Juan Bautista de Rossi en 1665, pues en él se designa con el nombre de Forum Hispanicum la parte de la plaza delante del palacio de la embajada, y quizá sea la primera vez que la plaza asume en la toponimia oficial el nombre con el que se la conoce a partir de entonces ${ }^{35}$. De todas formas en estos años el conflicto entre Francia y España por asuntos jurisdiccionales se había aplacado, porque Francia abandona la zona y centra su interés en el espacio contiguo al palacio Farnese, donde afianza su quartiere.

\section{LA LUCHA PONTIFICA POR LA ABOLICIÓN DE LOS QUARTIERI}

Durante el pontificado de Clemente X (1670-1676) se piensa en la abolición de la inmunidad de los barrios de los embajadores y se dan instrucciones precisas al nuncio Marescotti para que cuando llegue a Madrid aproveche cualquier oportunidad para reclamar la renuncia del embajador español al suyo ${ }^{36}$. En 1670, al poco tiempo de hacerse cargo de la nunciatura, se presenta la primera oportunidad. La reina gobernadora ordena a los representantes extranjeros que cierren las despensas, tiendas y otras inmunidades que disfrutaban por razón de franquicias en sus barrios porque podían favorecer el contrabando, establece la cantidad de productos que podían introducir y le obliga a pagar los

32 AlOISI, S.: «La scalinata tra storia e progetto», in La scalinata di Trinità dei Monti, Milán, 1994, pp. 43-94.

33 Fagiolo Dell'arco, M.: La festa barocca. Corpus delle feste a Roma, Roma, 1997, pp. 407-412.

34 Ibíd., pp. 414-419.

35 LUPARDI, B.: I luminosi splendori del sole nelle feste giocose..., Roma, 1662. Relación publicada por FAgiolo Dell'Arco, M.: La festa barocca..., pp. 414-419, afirma que en 1662 la voz popular ya la designaba con el nombre de plaza de España.

36 BEESS, ms. 448, ff. 272-275 (Instrucciones) y 286-311 (Copia de la correspondencia del nuncio con la Secretaría de Estado sobre el tema, 1671-1673). 
impuestos, que luego les rembolsa ${ }^{37}$. El nuncio, por ejemplo, recibe franquicia para introducir nueve arrobas de vino, seis capones y un cabrito al día; una vaca y un ternero a la semana; catorce cargas de pescado, 72 cerdos vivos y 80 arrobas de azúcar al año; dos arrobas de nieve al día en verano y una en invierno, dos cargas de aceite y otras dos de vinagre al mes, 156 arrobas de velas de sebo y cinco mil de carbón al año ${ }^{38}$. Y por franquicia de impuestos le devuelven 63.934 reales de vellón al año, que desde 1672 suben a 79.344 reales $^{39}$.

Poco después, la reina declara abolidos los barrios que tenían los representantes extranjeros y ordena a los embajadores que renuncien al mismo, sin reservarse más jurisdicción que la de su propia casa, "con apercibimiento de que si no lo observan daré parte a sus príncipes para que se lo manden». Acto seguido, los alguaciles entran en los barrios y realizan algunas detenciones de forma ostentosa, sin que proteste ningún embajador más que el de Venecia, porque habían detenido a un contumaz antes de recibir la orden real ${ }^{40}$.

Clemente XI aplaude la medida tomada por la corte española de suprimir los barrios para evitar los inconvenientes que ocasionan al buen funcionamiento de la justicia y de la real hacienda, y ordena al nuncio que renuncie al barrio como han hecho los demás embajadores en bien de la justicia y de la tranquilidad pública, con la esperanza de que también se haga así en la corte romana. Pero el marqués de Astorga, embajador español en Roma, no se da por enterado y no muestra ningún deseo de renunciar al cuartel. Ante ello, el nuncio suplica a don Pedro Fernández del Campo que interceda ante la reina para que ordene al marqués renunciar con prontitud, a fin de que los demás embajadores tomen ejemplo y hagan lo mismo ${ }^{41}$. Pero la corte de Madrid sólo manda al marqués renunciar a la despensa, no al barrio, donde sigue ejerciendo la jurisdicción, lo que pone en una situación incomoda al nuncio «que había renunciado a su quartiere con la esperanza de que España haría lo mismo al suyo en Roma» ${ }^{42}$. Ante esta situación, el cardenal Colombo, secretario de Estado de la Santa Sede, acusa al nuncio de haber renunciado de forma unilateral, sin haber exigido una reciprocidad por parte del embajador español, y le pide que repare el error y consiga que el marqués de Astorga haga lo mismo,

37 Hasta 1643 la franquicia consistía en poder introducir en Madrid, libres de derechos, los comestibles necesarios para el mantenimiento de la casa del embajador y su familia. Pero este derecho dio origen al abuso de establecer despensas o tiendas donde vendían públicamente los comestibles que no consumían, porque adquirían más cantidad de la necesaria, lo que perjudicaba a los intereses de la villa.

38 ASV, Segr. Stato, Spagna, vol. 141, f. 175. Franchigie et esentioni che godono in Madrid il nuncio apostolico e li ambasatori regii, 1671.

39 AGS, Estado, leg. 3120. Nota de lo que se paga al nuncio de franquicias por razón de sisas, 1671.

40 ASV, Segr. Stato, Nunz. Diverse, vol. 295, ff. 71-72. Nuncio a Cardenal Colombo. Madrid 6 mayo 1671.

${ }^{41}$ Ibíd., ff. 71-72. Nuncio a Pedro Fernández del Campo. Madrid 28 junio 1671.

42 Ibíd., ff. 75-78. Nuncio a Cardenal Colombo. Madrid 12 julio 1671. 
«para que haya una correspondencia en las resoluciones que aquí se quieren tomar para evitar los abusos y disturbios que su uso podría ocasionar si el embajador intentase oponerse a ceder sus derechos sin el preciso mandamiento de la corte. $\mathrm{Vd}$. ha sido engañado y se debe acusar a si mismo de haber cedido demasiado, derogando el honor de su carácter para comprar a tan alto precio la paz, y redimir los perjuicios que aquí se reciben y las protestas que sin duda el marqués empezará a practicar en esta corte» ${ }^{43}$.

El nuncio, ofendido por cumplir las órdenes recibidas, para justificar su conducta, presenta un memorial a la reina, quejándose de que mientras él había renunciado a su pequeño barrio de 24 casas el embajador español no lo había hecho al suyo, a pesar de ser mucho más extenso. Pues, si en Madrid se quieren suprimir los barrios de los embajadores por los abusos que se cometen y ser refugio de delincuentes, en Roma los abusos son mayores, porque los embajadores han extendido sus barrios mucho más que en Madrid, sin que el gobernador pueda ejercer la jurisdicción en ellos. Es decir, se ha introducido «en aquella santa ciudad una formal Babilonia para el refugio seguro de los delincuentes», sin ningún temor al castigo de sus actos y sin sufrir ninguna de las incomodidades que hacen menos grata la vida cuando se refugian en lugares comunes, pues en estos barrios hay espacios para toda calidad de personas. No faltan habitaciones muy cómodas para los caballeros, tiendas para los artesanos de cualquier especialidad, hosterías para los forasteros, donde pueden comer toda clase de alimenticios, almacenes de mercancías, plaza de vagabundos, estancos, casas de juego y prostitutas, seminarios de maldad y escuelas de los más atroces delitos. No contentos los embajadores con la extensión de sus barrios, en los que viven impunemente muchos delincuentes, pretenden que cualquier casa de la ciudad, que tenga sobre su puerta las armas de su corona, goza de inmunidad frente a la justicia romana, de forma que cuando un individuo comete un delito o es buscado por la justicia con poner sobre la puerta las armas del embajador la casa queda exenta de la jurisdicción pontificia. Además los embajadores han introducido el abuso de conceder patentes de familiaridad a personas de todo estado y condición que viven fuera del barrio, con lo que pretenden extender su jurisdicción más allá de sus confines, al otorgar la inmunidad con estas patentes. Con estas medidas la jurisdicción pontificia ha sido anulada prácticamente en amplias zonas de la ciudad de Roma, y si el papa quiere poner remedio al deterioro de su autoridad no tiene otra solución que abolir la inmunidad de los barrios de los embajadores, como se ha intentado hacer en Madrid. Con la particularidad de que los barrios de los embajadores en Roma, además de ser mucho más extensos, extienden su jurisdicción más allá de sus límites con la concesión de patentes de familiaridad ${ }^{44}$.

\footnotetext{
43 Ibíd., ff. 79-80. Cardenal Colombo a Nuncio. Roma 20 junio 1671.

${ }^{44}$ Ibíd., ff. 86-93. Memorial del Nuncio a la Reina. Año 1670.
} 
El Consejo de Estado examina el memorial del nuncio y sus miembros muestran pareceres diversos, aunque prevalece la idea de que era mejor dejar que el nuncio tuviera barrio en Madrid que perder el de España en Roma. El duque de Alba defiende su conveniencia como medio para hacer frente a cualquier levantamiento; el de Alburquerque dice que se puede permitir al nuncio tener el suyo, como una distinción respecto a los otros embajadores y por respecto a la Santa Sede, siempre que el papa haga lo mismo con el embajador español. El marques de Castel Rodrigo se muestra partidario de remediar los abusos del barrio, pero se opone a dejarle, «porque aporta gran lustre al embajador y, en las ocasiones que se precisan, dispone de la asistencia de mucha gente» ${ }^{45}$. El nuncio replica que el lustre del embajador no se apoya en el barrio sino en las muchas casas de príncipes romanos y del reino de Nápoles, pues con su ayuda puede reunir en poco tiempo la gente que necesita. Además, la supresión de los barrios beneficiaría al embajador español, porque seguiría contando con el apoyo de muchas casas nobles de Roma y de la cercanía de Nápoles, que los otros embajadores no tienen ${ }^{46}$.

El cardenal Altieri, además de aprobar la actuación del nuncio, le informa que el embajador español, marqués de Astorga, ya se había dado por enterado de lo que había sucedido en Madrid en torno a las franquicias y a los barrios, y que le había vuelto a pedir que pusiera remedio a los abusos que se cometían, expulsando a los ladrones, jugadores y delincuentes que allí se refugiaban. Le dice también que el papa estaba decidido a suprimir la inmunidad de los barrios y a restablecer la autoridad de los tribunales de la corte, siendo insoportable que los embajadores hayan establecido un tribunal en sus palacios para impartir justicia, cuando ésta es privativa del pontífice ${ }^{47}$.

El papa decide por fin reformar las franquicias de los embajadores y abolir sus barrios, «a fin de liberar a esta ciudad de los desordenes y de la detestable esclavitud de los quartieri». El embajador español, de acuerdo con las instrucciones de Madrid, se muestra propicio a renunciar a las franquicias, al igual que hace el del Imperio, pero no al barrio. Por ello, se encarga al nuncio que trate de conseguir un despacho real para que el embajador renuncie a la inmunidad del barrio, pues el papa no puede soportar por más tiempo «una inmunidad tan escandalosa y perjudicial al público reposo y está resuelto a reducirla al solo palacio del embajador ${ }^{48}$. De nada había servido el gesto del nuncio de renunciar al pequeño barrio de la nunciatura, ni tampoco los memoriales que entrega a la reina, pues el embajador español, con el apoyo de algunos miembros del Consejo de Estado, se opone a su renuncia y el nuncio Marescotti tiene que

${ }^{45}$ AGS, Estado, leg. 3119. Consulta del Consejo de Estado sobre los dos memoriales del nuncio. Madrid 18 julio 1671.

46 ASV, Segr. Stato, Nunz. Diverse, vol. 295, ff. 94-105. Nuncio a Cardenal Colombo. Madrid 15 julio 1671.

47 Ibíd., ff. 112-116. Cardenal Altieri a Nuncio. Roma 20 junio 1671.

48 Ibíd., ff. 117-119. Cardenal Colombo a Nuncio. Roma 4 y 18 julio 1671. 
reasumir el suyo para no quedar en condiciones de inferioridad ${ }^{49}$, aunque las autoridades españolas no respetan su inmunidad y los alguaciles siguen entrando con toda normalidad para hacer registros o detener a los perseguidos por la justicia que allí se refugian ${ }^{50}$.

Poco después, el nuncio presenta a la reina el breve pontificio sobre la decisión de abolir la inmunidad de los barrios de las embajadas en Roma para evitar los escándalos que ocasiona la exención, e informa verbalmente a los miembros del Consejo de Estado. Algunos consejeros le preguntan si la orden de abolición se refiere a todos barrios o sólo al de España, ante el temor de que no comprendiese al de Francia. El nuncio responde que la orden es general y que el papa no hará ninguna excepción con Francia, añadiendo que los representantes de Alemania, Francia, Portugal y Venecia no han protestado por el decreto de abolición y están dispuestos a ejecutarlo en cuanto tengan orden de su gobierno; por ello espera que se mande al embajador español que cumpla la orden pontificia. Y el nuncio termina diciendo al cardenal Altieri que «he exagerado de ser no solo conveniente dar orden al embajador de España en Roma para que obedezca enseguida, sino que sea el primero en declarase dispuesto a obedecer la orden, para que los otros embajadores tomen ejemplo de él para obedecer» ${ }^{51}$.

Al comenzar el año 1672 el nuncio recibe nuevas instrucciones sobre el tema de las franquicias y la exención de los barrios, y le advierten que si la corte de Madrid consigue que el embajador español en Roma se contente con la misma compensación económica que le han ofrecido a él por las franquicias, que acepte; pero si el embajador exige mayor cantidad el nuncio debe recordar el antiguo uso de la despensa y las ventajas de la nunciatura. En cuanto al barrio, si el embajador no quiere renunciar y contentarse con la inmunidad de su palacio, el nuncio debe restablecer la inmunidad del suyo y no permitir que sea turbada, «no siendo aceptable que el nuncio no conserve la jurisdicción en su barrio mientras el embajador la conserva». Y le advierten que no tolere ningún exceso y abuso, pues «así puede que se consiga con más facilidad el objetivo de Su Santidad, de forma que los embajadores se atengan a que su inmunidad no debe rebasar los límites de las casas de su familia, no teniendo ellos ni tribunales ni jurisdicción a que asistan los cánones y las leyes eclesiásticas» ${ }^{52}$.

El embajador español no renuncia al barrio y el gobierno de Madrid tampoco se lo manda. Lo único que le ordenan es que expulse a la gente de mal vivir y prohíba las casas de juego y todo aquello que pueda ser causa de embarazo con los ministros pontificios ${ }^{53}$. Ante esta actitud, el nuncio restablece el suyo y la despensa, y envía una protesta al ministro de Estado porque los al-

49 Ibíd., Arch. Nunz. Madrid, vol. 1, ff. 516-517. Informe del nuncio Marescotti. Año 1675.

50 Ibíd., Segr. Stato, Nunz. Diverse, vol. 295, ff. 127-131. Nuncio a Cardenal Colombo. Madrid 11 septiembre y 13 octubre 1671.

${ }^{51}$ Ibíd., ff. 132-134. Nuncio a Cardenal Colombo. Madrid 2 diciembre 1671.

52 Ibíd., ff. 136-143. Cardenal Colombo a Nuncio. Roma 26 marzo y 23 abril 1672.

53 Ibíd., ff. 145-146. Pedro Medrano a Nuncio. Madrid 27 noviembre 1672. 
guaciles no respetan su inmunidad y siguen haciendo detenciones. El ministro teme que el ejemplo del nuncio sea imitado por los demás embajadores y le ordena cerrar la despensa, pero se niega hacerlo hasta que el embajador español acepte la reforma de las franquicias establecida por el papa. Por otra parte, la medida del nuncio suscita agravios comparativos y el embajador de Francia dice a la reina que, de acuerdo con lo ordenado por su rey, había renunciado a la inmunidad de su barrio, siempre que lo practicasen los demás embajadores; pero si el nuncio restablece el suyo él hará lo mismo, de lo que da cuenta para que se ordene a los oficiales de justicia que se abstengan de ejecutar detenciones en él ${ }^{54}$.

Desde finales de 1672 el nuncio no encuentra ninguna dificultad para ejercer la jurisdicción en los confines de su barrio y hasta el final del pontificado de Clemente X (1676) no se vuelve a hablar del tema. El embajador español continúa ejerciendo la jurisdicción de forma pacífica, aunque durante la embajada del cardenal Nithard (1671-1677) su política transigente hace que se pierda parte de la jurisdicción del cuartel55. Incluso, cuando monseñor Millini es nombrado nuncio en Madrid en 1675, las instrucciones que recibe exponen los términos generales del problema, pero se limitan a ordenarle que aproveche cualquier ocasión para oponerse a la subsistencia del barrio del embajador español en Roma, cuya existencia es criticada incluso por el marqués de Astorga, antiguo embajador español en Roma.

«Confiesa el marqués de Astorga ser el quartiere pretendido por los embajadores una abominación, que destruye el gobierno, arruina los tribunales, impide el curso de la justicia, el comercio de los súbditos, la libertad y seguridad de los pueblos, anima a la gente de mal vivir a cometer delitos, defiende la inseguridad y produce tantos males que la experiencia ha demostrado deben atribuirse a este detestable abuso, el cual no solo no es honorable para la corona, sino peligroso por los problemas que puede ocasionar, siendo impropio y deforme que se haga caer la protección real sobre los ladrones, sicarios y la más abominable gente del mundo» ${ }^{56}$.

Las cosas cambian en el pontificado de Inocencio XI (1676-1689), pues el nuevo papa se enfrenta directamente con el problema y no duda en restringir la libertad de las sedes diplomáticas presentes en Roma, sin que las protestas de Venecia, España y Francia le hagan retroceder ${ }^{57}$. En la primera audiencia que el nuevo secretario de Estado, cardenal Cibo, tiene con el conde de Melgar,

${ }_{54}$ Ibíd., ff. 150-152. Nuncio a Cardenal Colombo. Madrid 15 junio 1672.

55 AGS, Estado, leg. 3120. Marqués del Carpio a Carlos II. Roma 1 mayo 1677.

56 ASV, Segr. Stato, Nunz. Diverse, vol. 295, f. 153. Capítulo de las instrucciones dadas a Mons. Millini, nuncio en España en 1675.

57 El pontificado de Inocencio XI ha sido poco estudiado, y así lo ha puesto de manifiesto SignorotTO, G.; «Dall'Europa cattolica a la crisi de la coscienza europea», en Religione, cultura e politica nell'Europa dell'età moderna. Studi oferti a Mario Rosa dagli amici, Firenze, 2003, pp. 231-249 
embajador extraordinario de España en Roma, le dice que el pontífice no está dispuesto a tolerar los desordenes que nacen de la exención de los barrios de los embajadores, que impide el curso de la justicia y favorece la impunidad de muchos delitos. Por ello, Su Santidad quiere que se respete de forma exquisita la inmunidad de las personas y de las casas de las familias de los representantes diplomáticos, pero que en las calles y plazas de Roma no se impida al gobernador pontificio ejercer la jurisdicción como se hace en otras cortes. El conde de Melgar se muestra comprensivo con el proyecto pontificio de abolir los barrios de las embajadas, y el cardenal Cibo se lo comunica al nuncio en Madrid para que coopere al buen fin del proyecto e indique al rey la voluntad del nuevo papa de no permitir que una parte de sus súbditos esté sujeta a los embajadores extranjeros y que éstos tengan más exenciones que las que tienen sus nuncios en otras cortes ${ }^{58}$.

«Por los escándalos e inconvenientes que resultan de los abusos introducidos en los cuarteles de los embajadores de los príncipes, en que se han hecho dueños absolutos de lo civil y criminal, impiden a la justicia su ejercicio libre y tienen reducida a servidumbre aquella ciudad y al pontífice a ser dueño sólo de poca parte de ella»59.

El gobierno se limita a responder que ha dado las órdenes oportunas al marqués del Carpio, nuevo embajador en Roma ${ }^{60}$, para que use de sus prerrogativas con moderación y respeto, de acuerdo con las instrucciones recibidas, gobernándose de forma que el papa no tenga motivo de queja ${ }^{61}$.

El papa se conforma con las garantías dadas por el gobierno de Madrid y el marqués del Carpio presenta las credenciales sin que le exijan ninguna declaración previa de renunciar a sus pretensiones. Unos meses después, cuando el cardenal Cibo le dice que el papa estaba pensando escribir a los soberanos para que renunciasen a los cuarteles por los muchos inconvenientes que ocasionaban y, que si no aceptaban, mandaría retirar los embajadores y sólo admitiría otros ministros inferiores, el marqués resalta la moderación que reina en el barrio español, «donde no hay juego, tabaquerías, ni hombres de mala vida, como le consta a su Santidad», y le indica que no le importaría renunciar al cuartel,

58 ASV, Segr. Stato, Nunz. Diverse, vol. 295, ff. 154-155. Cardenal Cibo a Nuncio. Roma 24 septiembre 1676; y Spagna, vol. 354, ff. 205-206. Cardenal Cibo a Nuncio. Roma 26 diciembre 1676.

59 AGS, Estado, leg. 3120. Nuncio a Carlos II. Madrid 20 febrero 1677.

${ }^{60}$ Don Gaspar de Haro y Guzmán, marqués del Carpio, hijo del que fuera valido de Felipe IV, es designado embajador en Roma a finales de 1671, pero no va a su destino hasta 1677. Demora su salida con toda clase de pretextos con la esperanza de que los reyes le llamen al valimiento. Sólo cuando don Juan José de Austria se hace cargo del gobierno, al ver fallidas sus esperanzas, se pone en camino. Cfr. AGS, Estado, 3117. Cartas de Carpio de 1672 a 1676 y consultas del Consejo de Estado.

${ }^{61}$ ASV, Segr. Stato, Nunz. Diverse, vol. 295, f. 157. Copia del billete del Secretario de Estado a Marqués del Carpio. Madrid 24 febrero 1677. Ver ANSELmI, A.: «El marqués del Carpio y el barrio de la Embajada de España...», pp. 563-596. 
porque le aporta más embarazos que ventajas, y le dejará con gusto si se lo ordena el monarca y lo hacen los demás embajadores ${ }^{62}$.

La alarma que produce en las cortes extranjeras la resolución pontificia de suprimir los barrios de los embajadores hace que los ministros romanos traten de tranquilizar a los soberanos, declarando que la mente del papa no era quitar los cuarteles sino restringirlos, al haberse ensanchado mucho desde el pontificado de Alejandro VII (1655-1666). El gobierno de Madrid acepta reducir el de su embajador, si todos hacen lo mismo, pero el rey francés dice que «no consentirá jamás se hiciese la menor novedad» ${ }^{63}$, con los cual el papa opta por su total abolición.

A pesar del buen entendimiento que durante los primeros meses parece reinar entre el marqués del Carpio y el pontífice, una serie de factores contribuyen a mudar las esperanzas en decepciones. El carácter poco dúctil del papa, el poderío francés y el comportamiento del marqués, que pensaba que la mejor forma de pedir era exigir, precipitan el desencuentro y el embajador presenta al nuevo papa como antiespañol y a su corte como interesada y desavenida. Y aunque sus afirmaciones no son aceptadas en un principio por el Consejo de Estado, algunos de cuyos miembros conocían directamente la corte romana, su insistencia contribuye a enfriar las buenas disposiciones anteriores ${ }^{64}$, y el marqués puede reivindicar y defender la inmunidad del barrio, supuestamente violada por la detención de una mujer de mala vida ${ }^{65}$, complicándose la situación con el problema de las franquicias, la recluta de soldados y el mejor trato que se daba al embajador francés.

$\mathrm{Al}$ entrar el marqués de Carpio en la embajada se hace construir carrozas y confeccionar libreas para sus criados por importe de sesenta mil escudos romanos, y pide a la Cámara Apostólica que le abone el 12 por 100, es decir, 7.200 escudos en concepto de franquicia. Cifra exagerada en comparación con los 1.095 escudos que había recibido su predecesor, don Pedro de Aragón, aunque había gastado 135.000 en su instalación. Inocencio XI le ofrece el 7 por 100 y luego publica un decreto, disponiendo que en adelante no se abonará más de dos mil escudos en concepto de franquicia, y sólo por las mercancías que entrasen en la ciudad ${ }^{66}$.

El marqués del Carpio se muestra insatisfecho con el decreto pontificio y sigue porfiando para rebasar el límite establecido, a pesar de que el Consejo de

\footnotetext{
${ }^{62}$ AGS, Estado, leg. 3120. Marqués del Carpio a Carlos II. Roma 11 julio 1677.

63 Ibíd. Consulta del Consejo de Estado, 2 septiembre 1677; y Marqués del Carpio a Carlos II. Roma 8 agosto 1677.

${ }^{64}$ Marques, J. M.: «Entre Madrid y Roma. La nunciatura española en 1675», Antológica Annua, (Roma) 26-27 (1979-80), p. 471.

${ }_{65}$ AGS, Estado, 3120. Marqués del Carpio a Carlos II. Roma 1 mayo 1677. Aunque el gobernador de Roma dice que la detención se había realizado fuera del cuartel, Carpio declara que pertenecía al cuartel y pide que el esbirro que realizó la detención sea desterrado y privado de su oficio.

${ }^{66}$ AGS, Estado, 3120. Resumen de los papeles del nuncio sobre inmunidades y franquicias de los embajadores y de lo que el marqués del Carpio ha escrito sobre esta materia.
} 
Estado le pide que proceda de acuerdo con los otros embajadores de las coronas ${ }^{67}$, pues piensa que el hecho de "que un hombre de su condición haya de pechar con las gabelas no es de crédito para la monarquía en Roma» ${ }^{68}$. Se refiere el marqués a una nueva disposición pontificia, según la cual no se bonificarían las mercancías compradas en la ciudad, sino sólo las que se llevasen de fuera ${ }^{69}$. El silencio posterior parece indicar que el marqués dejo de exigir los derechos que revindicaba. Pero quedaba abierto el problema de las mercancías introducidas por la aduana, pues aunque los aduaneros sospechasen que podían ser géneros de contrabando, su revisión podía ocasionar un incidente diplomático, como sucede en agosto de 1678, cuando el mayordomo del marqués se presenta en la aduana para retirar cuatro fardos de cuero de vaqueta, destinados a un comerciante romano. Carpio considera el control como una afrenta y propone pedir satisfacción, pero el Consejo de Estado le disuade ${ }^{70}$. En cambio, el Consejo sostiene que el embajador francés recibe mejor trato que el español en materia de franquicias y se amenaza a Millini y al nuncio en Nápoles con privarles de las que ellos gozaban, si la Cámara Apostólica no daba un testimonio fehaciente de lo que había cobrado el embajador francés ${ }^{71}$. Aunque el nuncio era partidario de darlo para cortar la controversia, el papa se niega, afirmando que el que quiera informarse puede consultar libremente los libros de la Cámara ${ }^{72}$. El asunto queda archivado y los incidentes posteriores de Carpio con las aduanas romanas se zanjan con las satisfacciones dadas por una u otra parte ${ }^{73}$.

La costumbre de reclutar soldados en el Estado de la Iglesia es continuada por el marqués del Carpio hasta que lo prohíbe el papa en septiembre de 1677, pero el rumor de que el marqués había reclutado por la fuerza algunos jóvenes y los había enviado a Nápoles, provoca un motín en Roma contra los españoles el 12 de septiembre. El embajador, temiendo que la manifestación llegase a su palacio, se prepara para la defensa, pide refuerzos al virrey de Nápoles y en señal de disgusto por los insultos contra los españoles deja de acudir a la audiencia papal y pide satisfacciones por lo acaecido. Exige, en primer lugar, que se detenga a los autores del memorial calumnioso sobre la violencia de las levas; segundo, que se proceda en justicia contra los promotores del motín y, tercero, que se de un bando informando que habían sido hallados algunos de los jóvenes supuestamente raptados por los españoles. El papa accede a las dos primeras peticiones y pide al nuncio en Madrid que solicite audiencia al rey para protestar por la actuación del embajador y del virrey de Nápoles, que se proponía acercar un batallón al Estado de la Iglesia y negaba audiencia al nun-

\footnotetext{
67 Ibíd., leg. 3120. Consulta del Consejo de Estado, 2 septiembre 1677.

${ }_{68}$ Ibíd., leg. 3057. Consulta del Consejo de Estado, 23 abril 1678.

69 ASV, Segr. Stato, Spagna, vol. 354, ff. 562-563. Informe al Nuncio. Roma 21 marzo 1678.

70 AGS, Estado, leg. 3059. Consultas del Consejo de Estado, 4 septiembre y 8 y 29 octubre 1678.

${ }_{71}$ ASV, Segr. Stato, Spagna, vol. 152, ff. 150-151. Nuncio a Cardenal Cibo. Madrid 2 octubre 1678.

72 Ibíd., vol. 355, ff. 56 y 71. Informes al Nuncio. Roma 16 abril y 20 mayo 1678.

73 AGS, Estado, legs. 3062 y 3063. Consultas del Consejo de Estado, 18 mayo y 22 junio 1680.
} 
cio de aquella ciudad. Carlos II se limita a darle buenas esperanzas y remite el asunto a consulta del Consejo de Estado, que recomienda pedir satisfacciones al papa, poner fin a la recluta de soldados y que Carpio no salga de Roma, a no ser en última instancia. Pero ante la amenaza francesa del milanesado, la resolución real se inclina por medidas más templadas. Se ordena a Carpio que se contente con el castigo de algunos promotores del motín, y a la vez que se amenaza al nuncio del peligro que podía sufrir si cerraba la nunciatura,

«no habiendo herida más sensible para la corte de Roma que entrar en algún recelo de que haya novedad con el nuncio que reside en esta corte, en los excesos envejecidos de este tribunal, como también en la dataría con los despachos de España» ${ }^{74}$.

El papa renuncia a pedir más satisfacciones y recibe al embajador. El marqués del Carpio acude a la audiencia papal, se da por satisfecho y pide, una vez más, que se castigue a los promotores del motín. Aunque algunos miembros del Consejo de Estado quieren aprovechar la situación para exigir nuevas satisfacciones, don Juan José de Austria impone una resolución conciliadora, exigiendo al marqués del Carpio que no pida más satisfacciones y castigue a los culpables de las levas, a la vez que ordena al virrey de Nápoles que admita al nuncio a su audiencia ${ }^{75}$.

Estos acontecimientos ponen de manifiesto, una vez más, que el prestigio español en Roma estaba muy menguado y el de Francia muy crecido, y determinan que la máxima de Carpio de utilizar mayor energía en las negociaciones con la corte romana vaya ganando cada vez más partidarios en el gobierno español, sobre todo en lo referente al quartiere, porque «los medios suaves son enteramente infructuosos para negociar con el papa y sus ministros» ${ }^{76}$. Es cierto que algunos ministros manifiestan al nuncio la buena disposición de la corte española para aceptar la abolición de los barrios de las embajadas en Roma, «que en pocos años se han hecho insoportables y se han convertido en vergonzoso refugio de la gente más facinerosa que hay en Roma», pero el marques no se muestra dispuesto a renunciar y amplia su jurisdicción a cuatrocientas casas más. De nada sirven los billetes que el nuncio envía a Roma con la supuesta orden del gobierno de Madrid para que renuncie. Carpio responde no haber recibido ninguna orden y el motín de septiembre enfría las relaciones, aunque el duque de Alba y don Jerónimo de Eguía digan al nuncio que el gobierno está dispuesto a condescender en su abolición siempre que los embajadores de otros príncipes hagan lo mismo ${ }^{77}$.

${ }_{74}$ Ibíd., leg. 3055. Consulta del Consejo de Estado, 12 noviembre 1677.

75 Ibíd., leg. 3056. Consulta del Consejo de Estado, 20 enero 1678. Con todo, en la carta que el rey escribe al papa el día 22 (ASV, Segr. Stato, Principi, vol. 105, f. 38) le sigue pidiendo el castigo para «los que en Roma atentaron contra la nación española».

76 ASV, Segr. Stato, Spagna, vol. 354, ff. 77-79 y 383. Cardenal Cibo a Nuncio. Roma 27 junio y 18 septiembre 1677 .

77 Ibíd., Segr. Stato, Nunz. Diverse, vol. 295, ff. 162 y 167. 
El cardenal Cibo pide al nuncio en París que sonde al gobierno francés si estaría dispuesto a moderar las franquicias y renunciar al barrio, reduciendo la inmunidad a la casa y familia del embajador, y Luis XIV se limita a decir que su embajador responderá al papa. Pero al decirle que el rey de España y los demás soberanos estaban dispuestos, el monarca francés le contesta que los demás podían hacer lo que quisieran porque eran dueños de su voluntad, «pero por su parte no quería que se hiciese novedad, ni en los cuarteles ni en las franquicias, ni vendría en ello, sino que corriese como hasta aquí». Y advierte al nuncio que si vuelve a hablarle de este asunto le mandará salir de la corte ${ }^{78}$.

El duque d'Estrèes, embajador francés, se encarga de dejar bien clara la posición de su rey con su actuación. Un francés hiere a un valenciano en una reyerta y se refugia en la iglesia española de Montserrat, que estaba dentro del cuartel francés. El embajador español pide al papa que se haga justicia, pero le responde que no podía hacer nada "porque en esa parte no se podía entrar porque es el cuartel de Francia». Unos meses después, se instala en este cuartel un hostelero para abrir una casa con licencia del papa, pero el embajador le dice que la licencia pontificia no sirve de nada, si no tiene la suya, y le da tres días para desalojar la casa. Cumplido el plazo, le expulsan y tapian la puerta de la casa a sus expensas, sin que nadie diga nada ${ }^{79}$.

Esta es la información que Carpio trasmite a Madrid y en lo sustancial se ajusta a la verdad, aunque el cardenal Cibo haga creer al gobierno español por medio del nuncio que Luis XIV accedía a la supresión de los cuarteles. A pesar de la negativa francesa, la corte romana decide pasar a la acción. No había problema con el barrio del Imperio, porque el cardenal Pío estaba como encargado de negocios, sin la condición de embajador; pero si con los de España y Francia. La solución podía consistir en que ambos embajadores renunciasen de común acuerdo, en que se ocupasen los dos de forma simultánea, o que uno renunciase primero, obligando moralmente al otro a hacerlo. Sin embargo, Inocencio XI se empreña en que sea España la primera en dejar el barrio, y se lo propone al marqués del Carpio, que responde negativamente con esta frase: «no quiero dejar semejante epitafio sobre mi sepultura» ${ }^{80}$. El nuncio trata de convencer al cardenal de Aragón de que la renuncia sería el mejor modo para aumentar el aprecio de la nación española entre los romanos, pero su muerte interrumpe la negociación ${ }^{81}$. Pasa entonces a tratar el tema con don Juan José de Austria y don Jerónimo Eguía, que no ven ninguna razón para preceder a Francia ${ }^{82}$, y entrega un memorial al monarca, representando «la gloria y el aplauso que le resultaría de ser el primero en mandar abolir el abuso del quartiere, en obligación del mayor afecto a Su Santidad». De momento no recibe

\footnotetext{
78 AGS, Estado, leg. 3119. Marqués del Carpio a Carlos II. Roma 19 septiembre 1677.

79 Ibíd., Marqués del Carpio a Carlos II. Roma 19 septiembre 1677 y 12 junio 1678.

${ }^{80}$ Ibíd., leg. 3055. Consulta del Consejo de Estado, 5 septiembre 1677.

${ }^{81}$ ASV, Segr. Stato, Spagna, vol. 150, f. 512. Nuncio a Cardenal Cibo. Madrid 14 octubre 1677.

82 Ibíd., ff. 579-580. Nuncio a Cardenal Cibo. Madrid 28 septiembre 1677.
} 
respuesta, pero se entera que el Consejo de Estado había examinado los informes llegados de París y de Roma, de que el rey francés se oponía a la pretensión del papa y no aceptaba que se quitase a su representante semejantes prerrogativas, cuando la corte romana había hecho creer a la española que París estaba de acuerdo ${ }^{83}$.

Mientras tanto, el 18 de octubre de 1677, Inocencio XI declara en el consistorio su decisión de abolir de forma terminante los barrios de los embajadores extranjeros y prohíbe que se pongan las armas de sus soberanos en las puertas para gozar de inmunidad ante la justicia pontifica. Al mismo tiempo, se encarga al nuncio que renueve las negociaciones con la corte española y procure que el rey católico sea el primero en aceptar la abolición del barrio, pero el duque de Alba le aclara que el gobierno sólo renunciará a las prerrogativas del barrio si lo hacen simultáneamente los otros soberanos. En el mismo sentido se pronuncia el Consejo de Estado, al declarar que si se suprimen los barrios a la vez el marqués del Carpio no se dará por ofendido, pero si se empieza por el de España, el embajador saldrá de Roma con los cardenales del partido, auditores de la Rota y demás dependientes ${ }^{84}$. No se desanima Inocencio XI por estas noticias y pide al nuncio que renueve sus oficios, aunque lo único que obtiene es el propósito de que el marqués del Carpio no se aliará con el embajador francés para formar un frente común en defensa de sus inmunidades, sino que hará lo que hagan los demás embajadores ${ }^{85}$. Pero tampoco esto se cumple, porque los dos embajadores se alían contra las pretensiones pontificias, aunque sus coronas estaban en guerra ${ }^{86}$. Con esta información bien podía decir el nuncio a don Juan José de Austria que la renuncia sería «un acto justo y glorioso», pues la buena disposición que tenía Francia había cambiado por la concesión pontificia de la décima para la guerra de Orán. Pero el valido le responde que sabiendo que Francia no renunciará, la dejación del barrio español sería inútil, al no ser imitada por los demás soberanos y, por tanto, España no renunciará hasta que lo hagan las demás coronas ${ }^{87}$.

El marqués del Carpio no tiene inconveniente en colaborar con el gobierno pontificio cuando trata con el mismo rasero a España que a Francia, como sucede con las patentes de familiaridad que los embajadores concedían a personas que vivían fuera de los barrios, colocando las armas de la corona en sus casas y carros para eximirse de la justicia pontificia. Inocencio XI da un edicto contra esta costumbre el 26 de noviembre de $1677^{88}$, y el embajador español después

83 Ibíd., Segr. Stato, Nunz. Diverse, vol. 295, ff. 164-166. Nuncio a Cardenal Cibo. Madrid 28 octubre 1677.

84 AGS, Estado, leg. 3055. Consulta del Consejo de Estado, 20 noviembre 1677.

85 ASV, Segr. Stato, Nunz. Diverse, vol. 295, f. 179. Duque de Alba a Nuncio. Madrid 6 enero 1678.

86 Ibíd., Segr. Stato, Spagna, vol. 354, f. 574. Cardenal Cibo a Nuncio. Roma 3 abril 1778.

87 AGS, Estado, leg. 3056. Memorial del Nuncio a Carlos II; y ASV, Segr. Stato, Spagna, vol. 152, f. 37. Nuncio a Cardenal Cibo. Madrid 3 febrero 1678.

${ }^{88}$ Una copia del edicto en AGS, Estado, leg. 3119. 
de consultar a los cardenales del partido anula todas las patentes ${ }^{89}$. En cambio, el francés se resiste hasta que la justicia romana entra en el palacio Sforza, a pesar de tener las armas de Francia en la puerta, con lo que se pone fin al abuso ${ }^{90}$.

Ante la resistencia de las coronas a renunciar al barrio, el papa no utiliza la fuerza, como algunos insinuaban ${ }^{91}$. Se limita a multiplicar sus declaraciones de que «si otros le perdían el respeto, estaba dispuesto a perdérselo para redimir a sus súbditos de las continuas injusticias que sufrían ${ }^{92}$. Declara que no privará del barrio a ningún embajador, pero tampoco admitirá a ninguno nuevo sino renunciaba previamente. Solución a medio plazo, pues tuvo que aguantar a Carpio y d'Estrèes, a quienes no veía con simpatía, porque sus monarcas los mantuvieron mucho tiempo en la embajada para no ceder el barrio. Venecia fue la primera que experimentó la inflexible voluntad del pontífice, pues al ser retirado el embajador Barbaro, el papa declaró que no admitiría a su sucesor Zeno mientras la República no renunciase a la inmunidad del barrio ${ }^{93}$. Venecia cede ante la firmeza del pontífice y el nuevo embajador renuncia al barrio en 1678, lo mismo que tiene que hacer el embajador polaco Radziwil antes de entrar en Roma en $1680^{94}$.

Aunque el nuncio no deja de quejarse ante la corte de Madrid de los continuos abusos que comete el marqués y su familia en el barrio, como los informes que envía Carpio son totalmente distintos, el gobierno le ordena que mantenga la inmunidad del cuartel y expulse a los esbirros pontificios que la violen, «sin permitir desigualdad de lo que se practica con el de los demás embajadores en aquella corte», y que así lo manifieste a los ministros pontificios ${ }^{95}$, que en sustancia es lo mismo que se responde al nuncio de que el rey estará encantado de complacer a Su Santidad siempre que la abolición sea general ${ }^{96}$. Pero el marqués del Carpio dice al gobierno que si quieren conservar el cuartel hay que ser más exigentes y no permitir o disimular que los esbirros pontificios violen su inmunidad, castigando con dureza a los que entren en el cuartel para que sirva de escarmiento $0^{97}$.

A pesar de la claridad de la respuesta que el gobierno había dado al nuncio, a mediados de 1680 vuelve a pedir que renuncie a la jurisdicción en el barrio

89 AGS, Estado, leg. 3056. Consultas del Consejo de Estado, 1, 19 y 20 enero 1678.

90 ASV, Segr. Stato, Spagna, vol. 158, f. 30. Cardenal Cibo a Nuncio. Roma 16 diciembre 1677.

91 AGS, Estado, leg. 3119. Marqués del Carpio a Carlos II. Roma 19 octubre 1677.

92 ASV, Segr. Stato, Spagna, vol. 354, ff. 569 y 574. Cardenal Cibo a Nuncio. Roma 3 abril 1678.

${ }^{93}$ Ibíd., vol. 354, ff. 669-670 y 735-737. Cardenal Cibo a Nuncio. Roma 10 julio y 16 octubre 1678. Más información en Bonaccorso, G.: «I veneziani a Roma da Paolo II a la caduta della Serenísima», in CALABI, D. e LANARO, P. (a cura di), La città italiana..., pp. 202-204.

94 ASV, Segr. Stato, Spagna, vol. 355, f. 437. Cardenal Cibo a Nuncio. Roma 10 agosto 1680.

95 AGS, Estado, leg. 3119. Despacho al Marqués del Carpio. Madrid 13 marzo 1680.

96 ASV, Segr. Stato, Nunz. Diverse, vol. 295, f. 190. Pedro de Aragón a Nuncio. Madrid 11 febrero 1680 .

97 AGS, Estado, leg. 3119. Consulta del Consejo de Estado, 30 julio 1680. 
por los delitos que cometen los facinerosos a la sombra de su inmunidad, pero obtiene la misma respuesta que en ocasiones anteriores, reiterando que el embajador español lo hará cuando los embajadores de testas coronadas renuncien a su jurisdicción,, «sin ser el primero ni el último» ${ }^{98}$. Al mismo tiempo se ordena a Carpio que, si el papa sigue con la idea de suprimir los barrios, actúe como los demás 99 .

Ante la ineficacia de las representaciones del nuncio, la corte romana amenaza a Carlos II con las censuras de la bula In coena Domini, declarando que se hallaba en pecado mortal si permitía la continuación de los abusos que se cometían por los malhechores que se acogían a la inmunidad del cuartel de la embajada,

«llegando esto a los términos de llamar el embajador aquel recinto una Ginebra, que ahora han crecido al acogerse allí la gente de mala vida que se alojaba en el barrio del embajador de Portugal después de su salida, lo que tiene a su Santidad en una suma desazón y escrúpulo de conciencia»100.

Al mismo tiempo, el nuncio dice al confesor real que los desastres de la monarquía podían ser la manifestación de la ira de Dios por los delitos que se cometían en el barrio. Las amenazas consiguen amedrentar al monarca, pero el Consejo de Estado quita hierro al asunto y trasmite su malestar al nuncio por la intimidación pontificia. Pero, a pesar de ello, el representante pontificio continúa protestando por la ampliación del cuartel que ha realizado el marqués del Carpio y por los escándalos, delitos, juegos prohibidos y desordenes que se suceden, amenazando que si no se remedian con prontitud la autoridad pontifica se verá obligada a intervenir para no perjudicar a la justicia. El marqués de Astorga le responde que el rey ha ordenado a su embajador valerse de la justicia pontificia cuando se cometan delitos y reducir su extensión a la que tenía en el tiempo de la embajada de don Pedro de Aragón y la suya ${ }^{101}$.

La presión del gobierno romano sobre el barrio de la embajada exaspera al marqués del Carpio que llega a decir que «neppur passaranno da quella parte $\mathrm{i}$ straordinari», y el marqués de Astorga recrimina al nuncio que el embajador de Francia recibía mejor trato que el de España y declara que la intención del rey no era otra sino que el marqués gozase del barrio como lo habían hecho sus antecesores, y en lo referente a su abolición deseaba que su ministro fuera tratado como los demás ${ }^{102}$.

98 ASV, Segr. Stato, Nunz. Diverse, vol. 259, ff. 192-193. Marqués de Astorga a Nuncio. Madrid 13 agosto 1681.

99 AGS, Estado, leg. 3119. Consulta del Consejo de Estado, 13 septiembre 1680.

100 Ibíd. Representación del Nuncio. Madrid 18 julio 1682.

101 ASV, Segr. Stato, Nunz. Diverse, vol. 295, ff. 208-209. Marqués de Astorga a Nuncio. Madrid 13 agosto 1782.

102 Ibíd., f. 19. 
Ante posturas tan enfrentadas, sólo cabía esperar a que cesasen los embajadores de España y Francia, pues la Santa Sede recordaba de vez en cuando que no admitiría nuevo embajador sin la renuncia a la inmunidad, como había hecho ya con el enviado de Polonia, Los ministros romanos reafirman la decisión pontifica y lamentan que haya personas «tan criminales, perversas y enemigas de Dios, de la justicia y del género humano», que defiendan el barrio del embajador, lleno de tantas abominaciones, y declaran que no queda otra solución que la de rezar para que Dios los ilumine y retraiga de su obstinación ${ }^{103}$.

Al llegar a Roma la noticia de que el marqués del Carpio había sido nombrado virrey de Nápoles, se ordena al nuncio que comunique por escrito al gobierno español que Su Santidad no recibirá al nuevo embajador sin que previamente renuncie a la inmunidad del barrio que habían tenido en aquella corte sus antecesores. Pero le responden que, siguiendo el dictamen de no ser el último en dejarle, mientras Francia no lo haga no renunciarán,

«pues sería monstruosidad ver en Roma otros embajadores con cuartel y el de S. M. sin él, cuya diferencia no puede querer Su Beatitud, y más cuando acaba de darse la providencia de corregir los desordenes que se cometían en él, mandando reducirle a los límites que por lo pasado ha tenido, que en esta materia no hay medio término, pues S. S. dice no recibir nuevo embajador manteniendo el cuartel, pero S. M. está fijo en no ser el primero ni el último en ordenar que se quite, y que por el obsequio que profesa a S. S. pasará a nombrar embajador luego que S. S. diese disposición para ello. Pero si S. S. persiste en no recibirle, no estará de parte de S. M. el que deje de ver el mundo todo lo que obra»104.

El marqués del Carpio, de acuerdo a las instrucciones recibidas, de que reduzca la extensión del cuartel a la que tenía en tiempos del marqués de Astorga (1667-171), se dispone a renunciar a la jurisdicción de las cuatrocientas casas que había incorporado, pero el papa no se conforma con ello, "por parecerle que con su limitación se adquiere posesión de inmunidad, que es lo que no quiere que se haga»105, y exige que renuncie a su totalidad, como había hecho el embajador extraordinario de Polonia. Pues, a su juicio, los barrios son una usurpación que se ha introducido recientemente, ya que «hace aproximadamente veinte años la justicia pontifica hacía libremente las detenciones en la plaza de España». Por ello rechaza la afirmación del marqués de Astorga de que compete a los embajadores alguna jurisdicción en su barrio, porque en Roma no hay otra jurisdicción que la pontificia ${ }^{106}$.

${ }^{103}$ Ibíd., Segr. Stato, Spagna, vol. 161, ff. 6 y 78. Cardenal Cibo a Nuncio. Roma 23 mayo 1683; y Nuncio a Cardenal Cibo. Madrid 17 julio 183.

104 AGS, Estado, leg. 3119. Marqués de Astorga a Nuncio. Madrid 4 septiembre 1682.

105 Ibíd. Consulta del Consejo de Estado, 20 octubre 1682.

106 ASV, Segr. Stato, Nunz. Diverse, vol. 295, ff. 210-215. Cardenal Cibo a Nuncio. Roma 13 septiembre 1682 . 
El 4 de septiembre de 1682 llega a Roma el correo de España con la nueva de que el marqués del Carpio había sido nombrado virrey de Nápoles, y apenas se difunde la noticia por la corte romana, el cardenal Cibo comunica al agente del rey, Francisco Bernardo de Quirós, que no se admitirá nuevo embajador sin que previamente renuncie a la inmunidad del barrio. El agente le responde que quizá en España tampoco se admitirá nuevo nuncio, si el papa sigue insistiendo en la total renuncia al cuartel. El rey aprueba la respuesta del agente y le ordena que procure defender con habilidad y maña la inmunidad del cuartel, según lo ha dejado el marqués.

«Por ser muy conveniente que S. S. se halle en inteligencia de que por mi parte se mantendrá la posesión en que estoy, sobre cuyo presupuesto se respondió a este nuncio la última vez que habló sobre esta dependencia en la forma que se contiene en la copia adjunta del papel que se escribió al marqués de Astorga, y en su correspondencia os gobernareis, valiéndoos de esta noticia por lo que mira a este punto, y procurando con maña que no se intente novedad en la manutención del recinto, según la limitación a que el marqués de Carpio la hubiese dejado»107.

Aunque Quirós, encargado de negocios, procura conservar el barrio y actúa con sumo cuidado para obviar todo motivo de queja de las autoridades romanas, apenas sale de Roma el marqués del Carpio para hacerse cargo del virreinato de Nápoles, comienzan a correr los rumores de la resolución del papa de apoderarse del cuartel. Quirós pide aclaraciones al cardenal Cibo, pero se limita a decirle que no tenía conocimiento de ello. El 8 de enero tiene audiencia con el papa y no hace ninguna alusión al tema. Pero en la mañana del día 14 el papa da orden a los esbirros de entrar en los cuarteles de Venecia y España, sin preceder más diligencias que comunicarlo una hora antes de ejecutarlo. Ese día pasan por las calles que había incorporado el marqués del Carpio y al siguiente lo hacen por las restantes, incluida la plaza de España, en forma ostentosa y provocativa ${ }^{108}$.

El encargado de negocios, al no poder recurrir a la fuerza para castigar a los esbirros, como le aconsejaban la razón y algunos vasallos y afectos al rey, se limita a protestar ante el cardenal Cibo, porque su violación suponía un atentado contra su rey y pide que se haga una pronta y equivalente reparación por el desacato cometido ${ }^{109}$. Acto seguido, informa a la corte de Madrid de los hechos, de la queja que había presentado al cardenal Cibo y de la excusa recibida de que no había tenido parte en ello, aunque le remite a las representaciones del nuncio de que el papa no aceptaría nuevo embajador con cuartel y que suprimiría su inmunidad una vez que el marqués del Carpio saliese de Roma, «porque no se podía castigar a los delincuentes ni probar el cuerpo del delito

107 BEESS, ms. 62, f. 145. Bernardo de Quirós a Carlos II. Roma 28 octubre 1682; y Carlos II a Quirós. Madrid 31 diciembre 1682.

108 AGS, Estado, leg. 3119. Bernardo de Quirós a Carlos II. Roma 17 enero 1683.

109 Ibíd. Bernardo de Quirós a Cardenal Cibo. Roma 15 enero 1683. 
porque todos se refugiaban en los cuarteles», y justifica la medida por la ausencia de embajador y no por menosprecio al rey. En los días siguientes los esbirros vuelven a violar la inmunidad del cuartel, "pasando por medio de la plaza y por las calles inmediatas, haciendo ejecuciones de justicia y ostentando jurisdicción en el cuartel». Quirós protesta de nuevo ante el cardenal Cibo, pero le responde que la inmunidad del cuartel no era una posesión de la embajada sino una usurpación que se toleraba al embajador; por eso, al salir de Roma, se había ejecutado la orden pontificia de no respetar la inmunidad de los cuarteles cuando saliesen los embajadores de las coronas, sin que se haya hecho novedad con el de España, pues antes se hizo con el Polonia y Venecia y se practicará con el de Francia cuando llegue el caso ${ }^{110}$.

La noticia de los hechos sorprende al Consejo de Estado, donde poco tiempo atrás se había sostenido que los repetidos avisos del nuncio de que no se respetaría el barrio al encargado de negocios, como tampoco le tenía el agente del Emperador, se debían exclusivamente a la natural fogosidad del ministro romano ${ }^{111}$. Los consejeros aprueban la actuación de Quirós y acuerdan protestar ante el nuncio por la injuria inferida a la corona por hacer pasar a los esbirros por el barrio, pero disienten de las medidas que se deben tomar para reparar la afrenta. Todos están de acuerdo en que se debe dar un escarmiento al nuncio, pero sin cerrar la nunciatura, aunque «toda el agua del Tíber no será suficiente para lavar la afrenta inferida». El marqués de Astorga piensa que el mejor remedio es enviar inmediatamente un embajador que restablezca el cuartel y pida satisfacciones, porque limitarse a quitar el cuartel al nuncio es corta satisfacción. Pero don Pedro de Aragón responde que para ser recibido por el papa tendría que renunciar previamente al cuartel y sería escandaloso que estuviera sin él mientras el de Francia continuaba con el suyo, pues cuando salga el embajador francés no está claro que el papa se atreva a ocuparlo,

«y en caso de hacerlo siempre se puede recelar de la altivez del Cristianísimo, que por lo menos saque alguna ventaja y nos resulte el desaire del haber de pedir reparación de lo que se concediere a los franceses, de lo que se seguirían graves inconvenientes de que no tenga el embajador de España por lo menos lo que toca al recinto del Palacio, por los muchos casos que se suceden cada día con tantos vasallos como hay de V. M. en aquella corte».

El almirante de Castilla aconseja aprovechar la coyuntura para suprimir todos los cuarteles en Madrid, pues aunque es corta satisfacción es una medida conveniente para el buen gobierno. El marqués de los Balbases apoya este parecer, empezando por el del nuncio y siguiendo por los demás, pues no habiendo cuarteles en Viena y París no pueden quejarse a sus soberanos ${ }^{112}$. Y esto

\footnotetext{
110 Ibíd.. Bernardo de Quirós a Carlos II. Roma 17 y 31 enero 1683.

111 Ibíd., leg. 3119. Consulta del Consejo de Estado, 26 noviembre 1682.

112 Ibíd. Consulta del Consejo de Estado, 18 febrero 1683.
} 
último es lo que se hace. Se manda a Quirós que no envíe más protestas al cardenal Cibo por la violación del cuartel y se declara abolida la inmunidad del barrio del nuncio sin darle opción a renunciar, ordenando al alcalde de Casa y Corte que tome posesión del mismo, lo que hace el mismo día que se publica la real orden. El nuncio al tener noticia de lo dispuesto, trata de salvar su honor saliendo de Madrid y encarga a un notario que levante acta de la entrada de los alguaciles y de su ocupación ${ }^{113}$.

Poco después, el gobierno español hace efectiva la supresión de los barrios de los embajadores que se había intentado en 1671. Una vez que la corte de Madrid obtiene la aceptación del emperador y aprovechando que no había ningún representante francés, en los primeros días del mes de agosto de 1684 se publica un decreto declarando suprimidos todos los barrios de los embajadores y representantes de príncipes extranjeros en el plazo de dos días. A partir de aquí, los oficiales de justicia pasan libremente por sus barrios, aunque por cortesía se informa a los embajadores, y sólo algunos criados del príncipe de Orange ponen resistencia, deteniendo a tres de ellos, mientras que en los demás no se produce ningún incidente ${ }^{114}$.

Aprovechando las medidas tomadas por el gobierno de Madrid, la corte romana reitera la necesidad de abolir los barrios y lo comunica oficialmente a todos los representantes de los soberanos, y el nuncio recuerda a la corte española que el nuevo embajador no será admitido si no renuncia previamente a su jurisdicción, ante lo cual el gobierno español decide aplazar su nombramiento ${ }^{115}$. Unos meses después se pregunta al nuncio si estaría dispuesto a entregar una declaración escrita, asegurando que jamás se concedería barrio a ningún embajador, y que el de Francia se suprimiría cuando marchase el duque d'Estrèes. Pues el Consejo consideraba que con este documento se podía soportar el agravio de que el embajador no tuviera barrio mientras el de Francia seguía teniéndolo. Sin embargo el papa se niega a dar tal escrito y el gobierno no lo vuelve a pedir ${ }^{116}$.

\section{DE LA RENUNCIA AL QUARTIERE A UNA INMUNIDAD LIMITADA}

El cardenal Millini deja la nunciatura de Madrid el 2 de octubre de 1685 y le sucede monseñor Durazzo, que sigue la misma política que su antecesor en el tema del barrio. Poco después de presentar las credenciales, comunica al marqués de Astorga la determinación del papa de no admitir al marqués de Cogolludo, propuesto para ocupar la embajada española ante la corte romana,

113 ASV, Segr. Stato, Nunz. Diverse, vol. 295, ff. 216-217 (Real orden. Madrid 23 febrero 1683), y 218-235.(Toma de posesión del barrio).

${ }_{114}$ Ibíd., ff. 236-239 y 241-242. Nuncio a Cardenal Cibo. Madrid 10 agosto y 5 octubre 1684.

115 AGS, Estado, leg. 3119. Consulta del Consejo de Estado, 2 enero 1683.

116 ASV, Segr. Stato, Spagna, vol. 161, ff. 87-88, 96 , 103 y 122. Nuncio a Cardenal Cibo. Madrid 12 y 26 agosto, y 21 y 30 diciembre 1683. 
si no lleva orden precisa de abandonar toda pretensión sobre el barrio ${ }^{117}$. De momento no recibe ninguna respuesta oficial, aunque le hacen saber oficiosamente que el nuevo embajador irá con intención de dar gusto al papa, estando pendientes del trato que se de al embajador de Inglaterra ${ }^{118}$.

En septiembre de 1686 se hace oficial el nombramiento del marqués de Cogolludo por embajador en Roma, y el nuncio comunica al rey la orden pontificia de «que no será recibido si no viene con orden expresa y con la determinación de abandonar el quartiere». En cuanto a las franquicias del equipaje le admiten todas francas, pero debe dejar que se revisen en la aduana para ver su contenido, como se ha practicado con los otros representantes reales ${ }^{119}$. El marqués de Cogolludo, general de las galeras de Nápoles, envía varios correos al encargado de negocios de la embajada sobre su pronta marcha para ponerse a los pies del papa, sin decir nada sobre el problema del barrio. Ante esto, Quirós pregunta al cardenal Cibo si el papa persiste en su decisión de no admitirle si no renuncia expresamente a él, y le responde «que si el señor embajador viene con la pretensión de querer el barrio no será recibido y en tal forma se ha escrito al nuncio para que lo participe al rey, a los ministros y al mismo embajador», entregando copia de la bula del 12 de mayo, en la que el papa declara abolida la inmunidad de los barrios, de forma que los contraventores incurren en las censuras de la bula In coena Domini ${ }^{120}$. En la audiencia que el nuncio tiene con el rey el 26 de junio le comunica la resolución pontificia de no admitir a ningún embajador sin que preceda declaración expresa de no pretender la inmunidad del cuartel y que, al no haberlo hecho todavía el marqués de Cogolludo, se hallaba en la precisa necesidad de exigirlo porque Su Santidad estimaba necesario esta precaución para evitar posibles equívocos. El rey se limita a responder que el marqués de Astorga había escrito al papa para saber si persistía en su resolución de que el marqués declarase que no pretendía el barrio, «aunque el embajador de Francia lo coja a la fuerza»121, como hizo Lavardín unos meses después ${ }^{122}$. Pocos días más tarde se responde al nuncio que se atenían a lo que habían dicho a su antecesor, mandando al marqués de Cogolludo no pretender el cuartel siempre que Su Santidad no se lo permita a otro embajador de corona,

\footnotetext{
117 Ibíd., Segr. Stato, Nunz. Diverse, vol. 295. Nuncio a Cardenal Cibo. Madrid 29 noviembre 1685.

118 Ibíd., f. 245. Madrid 4 abril 1686.

119 Ibíd., ff. 247-248. Cardenal Cibo a Nuncio. Roma 15 septiembre 1686.

120 Ibíd., ff. 249-251. Cardenal Cibo a Nuncio. Roma 1 junio 1687.

${ }^{121}$ Ibíd., ff. 252-254. Nuncio a Marqués de Astorga. Madrid 26 junio 1687.

122 El embajador francés, duque d'Estrées, muere el 30 de enero de 1687 y el papa, después de finalizar el entierro, ordena a los esbirros tomar posesión del barrio francés y el nuncio en París comunica a Luis XIV que no se admitirá al nuevo embajador si viene con la pretensión del cuartel. Pero el rey francés nombra embajador al marqués de Lavardín y le ordena que entre en Roma con una pequeña guarnición militar y tome posesión del cuartel, iniciándose un conflicto con el papado. Cfr. BEESS, ms. 405, ff. 48-51.
} 
«por lo que S. M. desea cooperar a los santos dictámenes de S. Beatitud en todo lo que no perjudique al decoro de sus ministros, y que se conozca lo que $\mathrm{S}$. M. deja a la recta y santa intención de S. Beatitud» ${ }^{123}$.

Mientras tanto, en la audiencia que el marqués de los Balbases tiene con el papa, para participarle el matrimonio de su hija con el príncipe de Avelino, surge el tema del franco y le dice que el marqués de Cogolludo no tenía ninguna pretensión sobre el barrio y que estaba dispuesto a venir con esa condición. El papa le responde que si el embajador viene con tal resolución será bien recibido y se respetara la inmunidad de su palacio, siempre que no de refugio a los delincuentes contumaces, de acuerdo con las disposiciones pontificias ${ }^{124}$.

Ante estas noticias, el marqués de Cogolludo renuncia a la inmunidad del barrio y pide galeras al virrey de Nápoles para emprender el viaje a Roma ${ }^{125}$. Desembarca en Ostia y, en compañía del condestable Colonia, el marqués de los Balbases, los dos auditores de la Rota y el encargado de negocios de la embajada, que habían salido a recibirle, se pone en camino para Roma, donde entra la noche del 3 de julio. Seis días después va a besar el pie de Su Santidad y visita a los cardenales de forma privada, al no haber presentado todavía las credenciales, lo que realiza después de declarar públicamente que no pretendía la inmunidad del barrio y que la inmunidad del palacio de la embajada no afectaba a los refugiados contumaces ${ }^{126}$.

El embajador, ateniéndose a las órdenes reales, había renunciado a la pretensión del barrio que habían tenido sus antecesores y otros embajadores de príncipes extranjeros, y que el embajador de Francia todavía conservaba ${ }^{127}$. Pero a los pocos día de entrar en Roma tiene que sufrir desaires y afrentas «de la vil canalla de los esbirros que sin necesidad pasan por las calles del barrio y delante del palacio haciendo escarnio y mofa del embajador y de su familia». El embajador protesta ante el cardenal Cibo y pide una satisfacción por la afrenta recibida $^{128}$. El gobernador de Roma replica que el paso de los esbirros no había sido para afrentarle sino para tomar posesión del barrio y mostrar públicamente que ya no existía tal inmunidad, como se había hecho en el francés haciendo

${ }_{123}$ ASV, Segr. Stato, Nunz. Diverse, vol. 295, ff. 256-257.Marqués de Astorga a Nuncio. Madrid 10 julio 1687.

${ }_{124}$ Ibíd., ff. 260-261. Cardenal Cibo a Nuncio. Roma 29 julio 1687.

125 Ibíd.., ff. 266-267. Marqués de Cogolludo a Carlos II, s.f.

126 Ibíd., f. 270. Cardenal Cibo a Nuncio. Roma 24 agosto 1687. El MARQuÉs DE ViLLAURRUTIA: La Embajada del Marqués de Cogolludo a Roma en 1677, Madrid, 1927, publica el manuscrito contra Cogolludo, una de cuya copias se conserva en la BEESS, ms. 67: El embajador de España incógnito conocido en la más notoria ignominia de su Rey, público en el mayor triunfo de Francia, manifiesto en los más engañosos tratados contra el Señor Emperador. El Marqués de Cogolludo en Roma.

127 AGS, Estado, leg. 3142. Instrucción reservada al Marqués de Cogolludo, nombrado embajador en Roma. Año 1687.

${ }^{128}$ BeEss, ms. 63, ff. 16-17. Marqués de Cogolludo a Carlos II. Roma 13 julio y 27 septiembre 1687. 
pasar a los condenados a galeras. Pero el marqués replica que los actos posesorios se ejercen ejecutando algún mandato en el distrito o persiguiendo y deteniendo algún reo por delito criminal, pero pasando sin motivo y sólo por hacer manifestación pública de su paso era un desaire y una ofensa al rey y a su representante,

«por ser aquel palacio propio de la corona, y se hacía a vuestra persona y calidad, como mi representante, y que aún fuera de esto, como a caballero de vuestra calidad no merecíais esta afrenta, cuando con tanto garbo habíais renunciado al cuartel por escrito, que no soñáis pretender, y que vuestra bizarría en dar gusto a Su Santidad y el acto heroico que habíais practicado antes que ningún otro embajador ordinario merecían atenciones y no afrentas»129.

Además, si el paso de los esbirros había sido para tomar posesión del cuartel, debían haberlo hecho cuando el marqués hizo la renuncia antes de entrar en Roma, cuando vivía en el palacio don Francisco Bernardo de Quirós, encargado de negocios y caballero particular que no tenía más dignidad que la de agente y procurador real, no cuando ya residía el embajador. Tampoco era equiparable el decir que los reos condenados a galeras habían pasado por el pretendido cuartel de Francia, porque lo habían hecho por vía Giulia, su camino habitual, donde estaban las caballerizas del palacio Farnese, y no por delante de la plaza como habían hecho en el barrio español, pasando por la plaza de España; pues si hubieran pasado por la parte de las caballerizas del palacio, aunque le hubiese molestado, no tendría tantos motivos de queja. El rey condena la afrenta y aprueba las medidas tomadas por el embajador, pero le previene que continúe las negociaciones con el cardenal Cibo sin tomar ninguna medida que pueda molestar al papa, «a quien deseo complacer en lo posible, pues cualquiera satisfacción que recibiereis siempre iréis a ganar el ser contradistinto de los demás ministros de coronas» ${ }^{130}$.

Sin embargo, a pesar de las palabras del rey de que no tomase medidas que pudieran molestar a Su Santidad, la aptitud desafiante del nuevo embajador francés, marqués de Lavardín, que entra solemnemente en Roma el 16 de noviembre de 1687 sin renunciar a las prerrogativas del barrio, a pesar de incurrir en las censuras de la bula In coena Domini, da ocasión a negociaciones en Madrid y Roma con el fin de que los embajadores de las coronas presenten un frente común en apoyo de Lavardín ${ }^{131}$. Aunque no llegan a ningún acuerdo, la amenaza influye en el cardenal Cibo, que se muestra dispuesto a dar satisfacciones al embajador español y a firmar un convenio sobre el comportamiento que deben tener los oficiales de la justicia romana en las cercanías del palacio de la embajada, reconociendo de forma implícita cierta inmunidad a un barrio

\footnotetext{
129 Ibíd., f. 156. Carlos II a Marqués de Cogolludo. Madrid 12 octubre 1688.

130 Ibíd., f. 17. Carlos II a Marqués de Cogolludo. Madrid 19 diciembre 1687.

131 ASV, Segr. Stato, Nunz. Diverse, vol. 295, f. 271. Nuncio a Cardenal Cibo. Madrid 4 marzo 1688.
} 
más reducido. De esta forma, se dispone que, aunque la autoridad pontificia tiene plena libertad para mandar pasar la policía por toda la ciudad, no lo hará por la plaza de España y sus cercanías sin avisar primero al embajador y por un motivo fundado de detener a algún delincuente. Y la zona en que se prohíbe el paso de los esbirros abarca toda la plaza de España, las calles Frattina, Borgoñona, Condotti, Carrozas y de la Cruz, que son las salen de la plaza, hasta la travesía de la Boca de León, más el palacio del marqués Núñez. A los acusados de delitos civiles se les puede conceder asilo de ocho a veinte días en la zona indicada, según la calidad del sujeto, y si en ese tiempo no pagan al acreedor deben abandonar el distrito o avisar a los esbirros para hacer la detención de forma conjunta; en cambio, a los acusados de delitos criminales, ya sean bandidos, asesinos o ladrones, no les puede dar asilo y, avisado el embajador para que retire su guardia, los esbirros pueden entrar para detenerles. El monarca español aprueba el acuerdo suscrito por el embajador con el secretario de Estado de la Santa Sede, cardenal Cibo, y le manda que lo registre en los libros de la embajada, para que esté en la memoria de sus sucesores ${ }^{132}$. En suma, se concede al embajador español una inmunidad restringida en el barrio, similar a la que el gobernador de Roma propone al papa que se conceda al embajador del Francia ${ }^{133}$.

Cuando muere Inocencio XI el 12 de agosto de 1689, el problema de la inmunidad de los barrios de los embajadores quedaba reducido al de Francia, cuyo embajador se niega a renunciar y lo convierte en un casus belli, bien conocido dentro de la historia de los papas, al mezclarse con el problema de los artículos galicanos. No obstante, con la destitución de Lavardín poco después y su salida de Roma, el gobierno pontificio toma posesión del barrio francés y declara abolida su inmunidad, como antes había hecho con el español ${ }^{134}$.

Con la abolición del cuartel francés parecía que el problema de la inmunidad en las zonas cercanas a los palacios de los embajadores pasaba a ser historia, pero no fue así, porque Inocencio XII (1691-1700) no prestó mucha atención a estas exenciones. Durante la guerra de Sucesión a la monarquía española los embajadores restablecen la jurisdicción en sus barrios, que mantienen con algunas limitaciones hasta que la república romana los suprime definitivamente en 1849 , pues aunque la república franco-romana declara suprimidas todas las jurisdicciones exentas en 1798, después se restablecen los antiguos privilegios y los embajadores recuperan la jurisdicción que ejercían en sus barrios ${ }^{135}$.

132 BeEss, ms. 62, ff. 157-158. Carlos II a Marqués de Cogolludo. Madrid 12 octubre 1688.

133 PASTOR, L.: Historia de los papas, XXXII, Barcelona 1952, pp. 283 y 288.

${ }_{134}$ Ibíd.., pp. 282-328; y NEVEU, B.: Correspondance du nonce en France Angelo Ranuzzi (16831698), I, Roma, 1973, pp. 142-167.

135 BEESS, ms. 60, ff. 13-20; y 63, ff. 201-226. Memoria del cuartel de España en tiempo del ministerio de Mons. Molines; y ff. 229-256. Memoria... en tiempo del ministerio del cardenal Francesco Acquaviva. 